\title{
Social-scientific criticism in Nigerian New Testament scholarship
}

\begin{tabular}{|c|c|}
\hline $\begin{array}{l}\text { Authors: } \\
\text { Kingsley I. Uw } \\
\text { Damian O. Od } \\
\text { Collins I. Ugw }\end{array}$ & $\begin{array}{l}\text { aegbute }{ }^{1,2} \text { (1) } \\
\mathrm{O}^{1,2} \text { (I) } \\
1^{1,2} \text { (1) }\end{array}$ \\
\hline $\begin{array}{l}\text { Affiliations: } \\
{ }^{1} \text { Department } \\
\text { Cultural Studie } \\
\text { the Social Scie } \\
\text { University of I } \\
\text { Nigeria }\end{array}$ & $\begin{array}{l}\text { feligion and } \\
\text { es, Faculty of } \\
\text { nces, } \\
\text { Jigeria, Nsukka, }\end{array}$ \\
\hline $\begin{array}{l}{ }^{2} \text { Department } 0 \\
\text { Testament and } \\
\text { Literature, Fac } \\
\text { Theology and } \\
\text { University of P } \\
\text { Pretoria, Soutr }\end{array}$ & $\begin{array}{l}\text { f New } \\
\text { Related } \\
\text { ulty of } \\
\text { Religion, } \\
\text { retoria, } \\
\text { Africa }\end{array}$ \\
\hline $\begin{array}{l}\text { Research Proje } \\
\text { Project Leader } \\
\text { Project Numb }\end{array}$ & $\begin{array}{l}\text { ct Registration: } \\
\text { r: E. van Eck (1) } \\
\text { er: } 2400030\end{array}$ \\
\hline $\begin{array}{l}\text { Description: } \\
\text { This research i } \\
\text { research proje } \\
\text { Platform for N } \\
\text { directed by Pr } \\
\text { van Eck, Depar } \\
\text { Testament Stu } \\
\text { Related Literat } \\
\text { Theology and } \\
\text { University of P }\end{array}$ & $\begin{array}{l}\text { s part of the } \\
\text { ct 'Africa } \\
\text { T Scholars', } \\
\text { of. Dr Ernest } \\
\text { rtment of New } \\
\text { dies and } \\
\text { cure, Faculty of } \\
\text { Religion, } \\
\text { retoria }\end{array}$ \\
\hline $\begin{array}{l}\text { Corresponding } \\
\text { Collins Ugwu, } \\
\text { collins.ugwu@ }\end{array}$ & $\begin{array}{l}\text { g author: } \\
\text { unn.edu.ng }\end{array}$ \\
\hline $\begin{array}{l}\text { Dates: } \\
\text { Received: } 16 \Lambda \\
\text { Accepted: } 09 \\
\text { Published: } 12\end{array}$ & $\begin{array}{l}\text { Jov. } 2020 \\
\text { May } 2021 \\
\text { July } 2021\end{array}$ \\
\hline $\begin{array}{l}\text { How to cite th } \\
\text { Uwaegbute, K. } \\
\text { Ugwu, C.I., 202 } \\
\text { scientific critici } \\
\text { New Testamen } \\
\text { HTS Teologiese } \\
\text { Theological Stc } \\
\text { a6394. https:// } \\
\text { 10.4102/hts.v7 }\end{array}$ & $\begin{array}{l}\text { is article: } \\
\text { l., Odo, D.O. \& } \\
\text { 21, 'Social- } \\
\text { ism in Nigerian } \\
\text { tt scholarship', } \\
\text { Studies/ } \\
\text { udies 77(1), } \\
\text { /doi.org/ } \\
77 \text { i1.6394 }\end{array}$ \\
\hline Read online: & \\
\hline 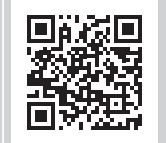 & $\begin{array}{l}\text { Scan this QR } \\
\text { code with your } \\
\text { smart phone or } \\
\text { mobile device } \\
\text { to read online. }\end{array}$ \\
\hline
\end{tabular}

The use of the social sciences in the interpretation of the New Testament emerged from the 1970s and has become a standard methodology for interpreting the New Testament. However, it has not been significantly used in the interpretation of the New Testament in Nigeria by biblical scholars. This article discusses what social-scientific criticism is and the need for its application in the interpretation of the New Testament by Nigerian New Testament scholars for a better understanding of the New Testament and the people, beliefs and teachings it presents and contextualisation in the face of changing contexts of Christianity in Nigeria.

Contribution: As far as we know, this article is the first one written on using social-scientific criticism to interpret the New Testament in the Nigerian context. It therefore contributes to the need for a multidisciplinary approach to interpreting the New Testament in Nigeria in particular and Africa in general. It therefore contributes also on methodological considerations with regard to interpreting the New Testament.

Keywords: New Testament; social-scientific criticism; New Testament scholars; Nigeria; biblical scholars; Christianity.

\section{Introduction ${ }^{1}$}

There is a modern awareness amongst scholars working with the New Testament on the need to understand the social world and people of the New Testament. In other words, scholars now believe that a thorough understanding of the social world and people of the New Testament will lead to a better interpretation and understanding of the teachings presented in the books of the New Testament. Martin (1993:125-126) aptly expressed that the desire to understand the world of the New Testament is not new. Kissi and Van Eck (2016:1) averred that what is 'fairly new and evolving' is the use of models and theories from the social sciences to interpret the New Testament. The belief that the texts of the New Testament are products of specific social systems (Elliott 2011:1-2) and that the use of social scientific models and theories will make for better understanding of the social systems out of which the New Testament texts grew is now very strong. This belief was the driving force of scholars who began to adopt social-scientific approaches in interpreting the New Testament as from the 1960s and 1970s (particularly) (Loumanen 2010:2) as shall be discussed in this article.

Today, the use of social-scientific approaches in interpreting the New Testament has indeed 'come to stay'. It has come to be regarded as a standard methodology for interpreting the New Testament. Indeed, it has yielded far-reaching results in the interpretation of the texts of the New Testament. However, in the context of New Testament scholarship in Nigeria, the social-scientific approach has little been appreciated and used. From our findings, this approach to the interpretation of the New Testament finds little support and usage amongst scholars and students of the New Testament in Nigerian tertiary institutions. This seeming 'apathy' to social-scientific approach in the interpretation of the New Testament in Nigeria is the motivation for this article. Hence, this article is aimed at describing social-scientific criticism (SSC) and its importance in interpreting the New Testament in Nigeria. It recognises the importance of African Biblical Scholarship (ABS) but seeks to argue for the need to supplement ABS with SSC in the quest for a better contextualisation ${ }^{2}$ of the New Testament texts in Nigeria.

1.The first version of this article was presented at the International Conference organised by the Faculty of the Social Sciences, University of Nigeria, Nsukka from 10 to 11 July 2019.

2.By contextualisation, we mean an art of interpreting New Testament texts in the Nigerian or African context(s) as the case may be. This does not negate our recognition that all methods of interpreting the Bible are contextual, be it the Western developed methods such as the historical-critical, narrative, literary and even social-scientific criticisms.

Copyright: (C) 2021. The Authors. Licensee: AOSIS. This work is licensed under the Creative Commons Attribution License. Note: Special Collection: Africa Platform for NT Scholars, sub-edited by Ernest van Eck (University of Pretoria). 
The article is structured as follows: Firstly, it discusses ABS as the dominant choice of biblical interpretation in New Testament studies in Nigeria whilst highlighting some of its limitations as it applies to the Nigerian context. Then it describes SSC as a methodology in the study of the New Testament. Next the gains and benefits of the use of such a methodology in the interpretation of the New Testament are discussed, followed by SSC in the context of the broader African New Testament Scholarship. Then the study highlights the current state of the use of social-scientific methodology in interpreting the New Testament in Nigeria and finally the study discusses the advantages of such a methodology for scholarship and the interpretation of the New Testament in Nigeria.

\section{The dominance of a focus in biblical interpretation in Nigeria: The case of the African Biblical Scholarship}

African Biblical Scholarship, as Mbuvi (2017:149-178) argued, is an emerging discipline. Justin Ukpong, the deceased Nigerian theologian whom West (2018:242) calls 'an ancestor of ABS', defined ABS as 'an encounter between biblical texts and the African context'. According to Dube and West (2000:11), ABS is not hesitant to address the past, present and future in the light of biblical texts. It is in this context that Mbuvi (2017:152) argued that 'ABS takes both the African and biblical realities as equal partners in dialogue, resulting in a distinctive juxtaposition of questions, approaches and interpretations'. By implication, ABS is an attempt by biblical scholars to interpret the Bible in the light of African (cultural) realities and real-life situation, both past and present. It is reactionary to Western methods of interpreting the Bible in Africa, which proved not to satisfy the yearning of African Christians.

According to West (2018:246), ABS is a post-colonial focus of interpreting the Bible in Africa because 'the Bible was brought to Africa as part of the missionary-colonial enterprise'. African Biblical Scholarship is equally tri-polar according to West (2018:247-248) because, in addition to the Bible and the African context interpreting each other, ABS adds appropriation in its method of interpreting the Bible. Finally, West (2018:254-255) argued that ABS is also a site-of-struggle because it deals with real-life struggle(s) of Africans in their own peculiar context(s). For Adamo (2016:6-8), ABS's distinctive features include the fact that it fosters communal reading of the Bible, depicts the Bible as power, argues for 'the presence of Africa and Africans in the Bible'. Adamo further pointed out that ABS aids a comparative reading of the Bible, African distinctive interest, 'using Africa to interpret the Bible' and the African identity and blackening the Bible. All these show the particularities of ABS and its importance in interpreting the Bible in Africa.

In the Nigerian context, beginning with the two periods of biblical interpretation in Africa pointed by Ukpong (2000:12), which were (1) the reactive-proactive (1970s-1990s) when
African context was used as a tool for biblical interpretation and (2) the proactive (1990s) which was when the African context became the focus of biblical interpretation, ABS has been the most dominant focus of interpreting the New Testament in Nigeria. Pioneers of this approach who included (but not exclusive) S.O. Abogunrin, E.N. Onwu (now E.N. Chinwokwu), D.T. Adamo, C.U. Manus and J.S. Ukpong, amongst others, read the Old and New Testaments through the African cultural eye(s) and context. The result of the works of these scholars was insightful as they did biblical interpretation in the light of the Nigerian context and experience. However, one thing that needs to be pointed out with regard to the works of some of these pioneers of ABS is that they lacked a clear-cut methodology. Apart from Ukpong (1996:189-210) who clearly called his method 'inculturation biblical hermeneutics', other pioneers of ABS in Nigeria did not develop a specific methodology through which they interpreted the Bible. Chris Ukachukwu Manus deserves a mention here. He followed in the steps of Ukpong and 'baptised' his method of doing ABS 'intercultural hermeneutics'. His method, if critically scrutinised, is Ukpong's inculturation hermeneutics garbed in another name. In Manus (2003:40-45), we see him apply this method to Mark 1:40-45 in the context of the problems of human immunodeficiency virus and acquired immunodeficiency syndrome (HIV and AIDS) in Africa where hope, compassion and moral support could be learnt from the text and applied in the context of those living with the pandemic in Africa.

Like those before them, most New Testament scholars in Nigeria today use ABS in their study and interpretation of the New Testament. The reason is that it is the tradition they received, being trained mostly in Nigerian religious or theological departments where ABS has dominated biblical interpretation for a long time. ${ }^{3}$

However, in all its good intention and work, ABS has its own peculiar limitations and challenges. Adamo (2016:1-10) and Asaju (2005:121-129), for example, articulated some of the limitations and demerits of ABS to include accusations of fetishism and syncretism, which all related with African Traditional Religion. In this regard, Asaju (2005:121) argued that ABS has been labelled 'a return to African Traditional Religion' by its critics. This is a fact that Kato (1975) recognised and had pointed it out as a theological pitfall in Africa. Some other limitations of ABS include the accusation of being too local and un-universal for biblical interpretation (Adamo 2016:4).

Aside these criticisms, we point out other limitations of ABS, particularly in the Nigerian context. Firstly, the non-use of models and theories of related social sciences in explaining cultural issues found in the New Testament (Bible) counts against ABS. As part of the goal of ABS is to 'interpret the New Testament in the light of African culture(s)' as Le Marquand (2000:72-102) pointed out, then there is every 3.In one of his arguments in the defence of $A B S$, one senior colleague in our department said that they use the ABS because it is what they inherited from those who taught them. 
need to incorporate cultural anthropological theories and models, for example, in interpreting the New Testament, firstly in the context of its 1st-century actors and secondly in the cultural context of Christians in Nigeria. The users of ABS fail to see this need, or think it irrelevant to the cause of biblical interpretation in Nigeria. Secondly is the problem of modernity and the changing contexts which Christians find themselves in Nigeria today, particularly those in the urban areas. In reality, the practice of Christianity in Nigeria has been heavily affected by modernity. As such, a large number of Christians in Nigeria, particularly the youth and the Pentecostals, do not see much relevance in cultural practices with regard to their pursuit of 'good or modern life', all due to modernity and globalisation. These have indeed shaped some Christians' view of their culture and its place in the practice of Christianity in Nigeria. Biblical scholars in Nigeria should take cognisance of this fact and recognise that making Nigerian culture an integral part of biblical interpretation may not appeal to modern-day Christian sensitivities.

Thirdly, the myriad of problems facing Christians in the Nigerian context are many now. From terrorism or religious violence to corruption to poverty and hunger, amongst others, Christians in Nigeria are faced with socio-economic and religio-ethnic problems. Hence, interpreting the New Testament to make sense to victims of terrorism who are Christians, for example, may also demand a sociological and psychological foregrounding of, firstly, texts dealing with this issue, and, secondly, the context in which the text is interpreted. This will lead to understanding of the text being interpreted better and the people to which the text is being interpreted. This is what ABS often fails to deliver on.

\section{Social-scientific criticism as a methodology in the interpretation of the New Testament ${ }^{4,5}$}

The interest in understanding the social conditions relating to the texts of the New Testament predates SSC. As Martin (1993:125-126) pointed out, other scholarly movements such as the history of religions school, the form critics and the Chicago school of the New Testament had all, at one point, been interested in connecting social analysis of the New Testament world with the texts of the New Testament. Meeks (1983:3) also pointed out the fact that the Marxist school and the Chicago school of the New Testament have all tried to do a social analysis and interpretation of the New Testament at one point or the other. Therefore, these schools of thought may be called the precursors of SSC

4.For related literatures on SSC, see Pilch (ed. 2001), Malina $(1982,1983)$, Esler (1995), May (1991), Malina and Rohrbaugh (1992).

5.Social-scientific criticism has been accused of using abstract models in interpreting the Bible, and most of all, Eurocentric. We follow Esler's (1994:12) point that what is important is the usefulness of these models in interpreting a text and reaching the desired goal of the exegete. After all, these models are mainly 'heuristic tools of overcoming cultural distance between modern individualistic culture and the overcoming cultural distance between modern individualistic culture and th ancient Mediterranean culture' (Loumanen 2010:4) and have mostly been developed, proven and used in Social Sciences researches. On the Eurocentric nature of social and scientific criticism, we point out that it is to be borne in mind that biblical interpretation as a field of study is a product of the West; it originated in the West and as such cannot be divorced from its root. Therefore, those who accuse SSC of Eurocentrism are also guilty of practising an art traceable to the West, no matter how uniquely African, it can be argued, ABS is.
(Martin 1993:125-127) (henceforth called SSC in this article). What differentiated the social analysis of these schools of thought and SSC was using theories and models from the social sciences to interpret the New Testament by the scholars who began adopting SSC as a methodology (Elliot 2008:26-36; Martin 1993:132-138).

It was precisely during the 1960s and most notably the 1970s that using theories and models taken within social sciences courses such as Sociology, Cultural Anthropology and Social Psychology were applied to New Testament texts. The result of these theories and models were far-reaching; it provoked thought as to whether New Testament texts can be opened to such interpretations. From Gager (1975), Theissen (1978), Elliott (1981) and Meeks (1972, 1983), thoroughgoing sociological and social psychological models and theories were applied to specific texts of the New Testament and their social history. The result of these was penetrating just as it was far-reaching and insightful.

During the 1970s, however, this approach was still without a recognised name. Whilst some referred to it as 'social description/history' (examples include Smith 1975; Wilde 1974), it was not until 1981 that J.H. Elliott gave it the name 'Social-Scientific Criticism' (Elliott 2008:29). It is worth mentioning that using the social sciences in the interpretation of the Bible became more manifested since 1986 when a group of international biblical scholars who called themselves 'The Context Group' pledged their commitment to using the social science in the study of the Bible. Notable amongst these scholars were J.H. Elliott, B.J. Malina, D. Duling, P. Esler, D.E. Oakman, J. Neyrey, R.L. Rohrbaugh, W. Stegeman, S.S. Bartchy, K.C. Hanson and J. Pilch, amongst others.

\section{According to Elliott (2011):}

$[B]$ iblical texts, like all texts, embed, encoded, and presumed elements of the social and cultural system in which they are produced, which means that the genre, content, structure and meaning of these texts are socially and culturally determined. (p. 1)

This is why Elliott $(1993: 7,2011: 1)$ defined SSC as the analysis of the social and cultural dimensions of the texts and of its environmental context through the utilisation of perspectives, theories, models and research of the Social Sciences'. Nyiawung (2010:121) added that SSC is 'an exercise in which theories and models of the social sciences are used in order to analyse textual and referential words'. In this regard, it is good to note that SSC is a method of biblical interpretation or what is commonly called exegesis in biblical studies. Its uniqueness lies in the fact that it studies New Testament texts through the models, theories and perspectives of the social sciences.

At this point, it is considered pertinent to describe what models and theories are. According to Bacharach (1989), a theory is: 
[A] system of constructs (concepts) and propositions (relationship between those constructs) that collectively presents a logical systematic and coherent explanation of a phenomenon of interest with some assumptions and boundary conditions. (pp. 496-497)

A research model on the other hand is used to describe the overall framework used to study reality, based on a philosophical stance (Clarke 2005:13). Models identify basic concepts and describe what reality is like and the conditions by which these can be studied (Clarke 2005:13). Seen from these perspectives, the aim of SSC is therefore to use the theories and models of the social sciences, particularly those of Sociology, Cultural Anthropology and Social Psychology, to study the New Testament. This is to be able to explain and understand better the behaviours, people, culture, politics and teachings we come across in the New Testament texts. However, we also point out that one area of disagreement by scholars who use the social sciences in interpreting the New Testament methodology has been on the issue of the suitability of particular models for particular New Testament texts. That notwithstanding, we follow Esler's (1994) thought that:

$[I] \mathrm{t}$ is inappropriate to debate whether a model is 'true' or 'false', or 'valid' or 'invalid'. What matters is whether useful or not, although usefulness is most unlikely without a fair degree of comparability between the model and data. (p. 12)

With regard to steps taken in interpreting biblical texts using SCC, we make reference to Elliot's (1993) discussion on the subject. According to him, SSC begins with the following presuppositions:

1. Knowledge is socially conditioned.

2. Analytical method must provide a means to distinguish social locations.

3. Models are a means of finding meaning.

4. There should be an employment of abduction or retroduction.

5. Models must be based on circum-Mediterranean and ancient near-eastern emic data.

6. Linguistic presuppositions regarding the text should be included.

7. SSC is both distinct and complementary to the historical approach.

8. The study of social structure is the basis for the study of religion in the Bible.

9. A recognition of the aggregated meaning of Bible documents.

This then leads to what Elliot calls phases of SSC as a method. The first one is the collection of data and its organisation. The second phase is the task of interpretation and explanation of social properties and relations (for more on this topic, see Drovak 2007:541-576).

Following these, Elliott had applied these steps in his 1981 epoch-making work where he applied the theory of 'conversionist sectionalism' to the letter of 1 Peter and argued that the writer of the letter considered the community of the Letter $(1 \mathrm{Pt})$ as a sect which were resident aliens or displaced strangers of Asia Minor when the letter was written. Thus, the social situation of the letter according to Elliot was that of conflict. Hence, for Elliott the strategy of the letter was to use the social situation of the community to strengthen in-group cohesion, which will allow it to have a common identity in the society the community found itself. This leads to the letter's promotion of the Christian community as the household of God and gives what roles are expected from each member of that household.

Another proponent of SSC whose work deserves a mention is Philip Esler whose main focus is on the use of social psychological theory of social identity in interpreting the New Testament. As it stands, Esler is the first scholar to apply social identity theory to a New Testament text in 1996. This was seen in his work on Galatians 5:13-16 dealing with group boundaries and intergroup conflicts. To illustrate Esler's method, we refer to his 2003 work on Romans in which he applied the social identity theory in determining the social setting of the letter. Firstly, Esler clearly defines both Roman and Christian identity at the time the letter was written. Then, he explains his methodology which is the social identity theory. Next, he explains the dynamics of ethnicity and ethnic conflicts in the Mediterranean context. He also discusses the purpose of the letter in the light of verses 1:1:15 and 15:14-16:27. Then, Esler relates to the common in-group identity in verse 1:1-3:20 and the foundations of this new identity as seen in verse 3:21-31. This leads, according to Esler, to Paul's teaching on Abraham as a prototype of group identity in verse 3:21-4:25. It is followed by Paul's teaching on the origin of the new identity in Christ including Pauline leadership and group exemplification in chapter 7 and the exalted character of this new identity in Christ as taught by Paul in chapter 8.

\section{The importance of social-scientific criticism in interpreting the New Testament: A brief analysis}

The question that arises here is, 'what are the advantages of interpreting the New Testament through the eyes of SSC?' Firstly, interpreting and studying the New Testament through SSC leads to a culture-sensitive interpretation of the New Testament, especially regarding that of the 1st century AD Mediterranean world. Often, most readers and interpreters approach the New Testament with an ethnocentric bias. As some scholars such as Bailey (1983, 2008) have long pointed out, this is highly misleading. In a modern world like ours, it is rampant to see scholars interpret the New Testament with modern (Western) cultural assumptions, which, in most cases, are imposed on the understanding of texts. This leads to reading texts offcontexts because the cultural world out of which the New Testament texts grew is different from that of the modern world. The Mediterranean concepts of kinship, honour, patronage, shame, family/family codes and behaviours, for 
example, are different from those of the modern individualistic world. Some of these are what one comes across in the New Testament (Elliott 1993:10). How does one understand and explain some of these concepts if not through the models and theories of Cultural Anthropology and Sociology, especially in relation to peasant (agrarian) societies to which the Mediterranean world belonged during the 1st century AD? (Longnecker 2010; Van Eck 2009a). Here again is the need for cultural anthropological and sociological theories and models in explaining these social institutions. Hence, a culture-sensitive reading of the New Testament texts calls for the adoption of related theories and models of related social science courses.

Secondly, interpreting the New Testament through SSC recognises and places the New Testament firmly within the agrarian and exploitative Mediterranean world of the 1st century $\mathrm{AD}$ as dominated by the Roman empire and its Jewish aristocracy. To understand the power structure of that world entails the application of both political anthropological and sociological models relating to agrarian societies as the case maybe. In the gospels especially, one comes across how this Roman/Jewish elite power structure played out, including Jesus' critique of them (cf. Mt 20:20ff., Lk 13:1-15, 18:1-18, 20:45ff.).

Thirdly, the adoption of SSC in interpreting the New Testament does not encourage theological reductionism. Meeks (1983:4-15) raised the point that to claim that the New Testament texts cannot be studied through the application of social scientific theories and models amounts to theological reductionism. And Meeks was right to a large extent. Granted, the New Testament presents teachings about God. Thus, it is the word of God. However, it would be fallacious for one to claim that this 'word of God' presented in the New Testament can be studied independent of the sociocultural context out of which it grew. The people who were the actors, writers and recipients of this 'word of God' had their own behaviours, thoughts, understandings and beliefs. These were influenced by their sociocultural contexts that were evident in the teachings and 'practices' presented in the texts of the New Testament. Therefore, to claim that these can only be explained theologically is being 'reductional'. This is exactly what using SSC in studying the New Testament guards against.

Fourthly, for African scholars who push for contextualisation, interpreting the New Testament texts with SSC offers the possibilities of doing a cross-cultural interpretation of these texts. Thus, we found Nyiawung's (2010:121) assertion useful here. According to him, 'the SSC being a diachronic method of exegesis is an interaction or comparison between first century Palestine and new context in which biblical interpretation is carried out'. For the contextualisation of the New Testament texts, the use of SSC offers a better comparison of the 1st century Mediterranean world of the New Testament and that of African cultural, political and social contexts. The results of this comparison afforded by
SSC are always fruitful because the similarity of the world of the New Testament and that of the African world is much (Chinwokwu 2015:271-272, 277).

\section{Social-scientific criticism in the African biblical (New Testament) context: From Van Aarde, Draper, Craffert to Van Eck and others}

With the formation of the context group, which is a group of international scholars committed to using SSC in interpreting the New Testament, as we have shown above, some South African scholars entered into the use of SSC in interpreting the New Testament. One of the earliest of these South African scholars to have become a member of the Context Group was Andries van Aarde of the University of Pretoria. Beginning from the 1980s, Van Aarde published works that used perspectives from the social science to interpret the New Testament, particularly the gospels and the historical Jesus (De Villiers 2011). Van Aarde (1993), Van Aarde (1994), Van Aarde (1997), Van Aarde (2002), Van Aarde (2004) and Van Aarde (2008), amongst other works, reflect Van Aarde's successful application of SSC to New Testament texts and issues. Jonathan Draper, a South African New Testament scholar of the University of KwaZulu-Natal, also deserves recognition for some of his contributions to use SSC in the study of the New Testament. Although mostly concerned with orality and performance and contextual reading of the New Testament in South Africa, Draper has produced critical works that used SSC in the interpretation of the New Testament. Examples include Draper (1992:13-29), Draper (1995:183-202) and Draper (1998:541-576), where theories and models from Sociology were used in his approaches to the New Testament issues he treated.

Another member of the Context Group is Pieter Craffert of the University of South Africa. Although having many works dealing with the use of SSC in interpreting the New Testament, particularly the historical Jesus, Craffert (2008) successfully developed and applied his theory of 'shamanic complex' ${ }^{6}$, a theory domiciled within Anthropology, as a model in the study and understanding of the historical Jesus. Fellow members of the Context Group such as John Pilch, Richard Rohbaugh and Bruce Malina sang the praises of Craffert for using the shamanic complex as a key to understanding the historical Jesus (see Van Aarde [2008:772]). Like his fellow countrymen, Van Eck (2009:310-321, 2013) used SSC to interpret the parables of the Jesus in the gospels with huge success.

A former student of Van Eck, Mbengu D. Nyiawung who is a Cameroonian, deserves a mention with regard to using SSC, particularly in contextual reading of New Testament texts in Africa. Nyiawung (2010) was able to apply both SSC and narratology as methodologies in his study of leadership and conflict from Lukan (9:18-22) perspective as it applies to the African context, thereby proving the possibility of providing

6.For a critique of Craffert's work, see Van Aarde (2008:67-797) 
a contextualised reading of New Testament texts in Africa using SSC as a methodology. Our brief survey of the use of SSC by African scholars shows that SSC is neither new nor strange in biblical interpretation in Africa. Although the works of most of these South Africans discussed here are not contextual, they show the fact that SSC can be used to study the New Testament by African scholars and in the African context. Nyiawung's work, as we have indicated, showed the possibilities of doing a contextual reading of New Testament texts using SSC as a methodology. By implication, there are great possibilities of doing ABS using SSC as a methodology. After all, it seems that ABS uses eclectic methodologies in interpreting the New Testament texts. This may be why even African biblical scholars who do ABS disagree on methodologies suitable for the cause of biblical interpretation in Africa (Nyiawung 2013:7).

\section{Social-scientific criticism in New Testament interpretation amongst biblical scholars in Nigeria today}

We have shown that the most dominant method of New Testament interpretation in Nigeria is ABS despite the benefits of the use of SSC in studying the New Testament. With what we found out, only a few Nigerian biblical scholars have dared to adopt SSC in the study of the New Testament, especially in the Nigerian context. A survey of these few works showed that these Nigerian scholars were mostly products of non-Nigerian Theological and Religious Studies departments, with the exception of a few. These scholars showed how possible SSC can be successful in contextualising the New Testament in Nigeria. A brief illustration of these scholarly works will prove our point. Ogunbanwo (2011) studied Jesus' attitude to the outcasts in Luke in the context of Yoruba Christians' attitude as it pertains to people living with HIV and AIDS in Anglican Dioceses of Ijebu-Remo of Ondo State Nigeria. Ogunbanwo (2011) adopted the Social Anthropological theories of body as a social map and labelling/deviance ritual of Mary Douglas and Becker Howard in reading selected texts of Luke where Jesus had encounters with the outcasts. The application of Ogunbanwo's work to the Yoruba Christians challenged the stigmatisation of people living with HIV and AIDS. Madubuko (2015) applied the psychological theory of cognitive restructuring in his interpretation of Ephesians 3:10 in the Igbo context. The result of his work showed that the Igbo people have a deep fear of the spirit world which hampers the practice of a genuine and mature faith amongst the people. Madubuko therefore advises that the Igbo people have a cognitive restructuring of their mind with regard to dealing with the spirit forces of their world for the practice of a mature faith, including the betterment of the Igbo society.

Okoye (2018) applied the social identity theory of Henri Tajfel in his reading of Acts 6:1-6 in the context of social identity and intergroup relations in Nigeria. Okoye argued that it was the problem of social identity that was at play in the case of the discrimination that the Hellenists suffered in the hands of Palestinian Jews. Such a problem occasioned by social identity, as Okoye argued, plays itself out in the context of group relations in Nigeria that breed religious violence, ethnicity, social injustice, rancour and bitterness, which have all hampered peaceful relations amongst Nigerians. Uwaegbute and Odo (2018:333-357) applied the psychological theory of religious coping in their interpretation of Romans 8:35-39 as it relates to Igbo Christianity. They contended that part of Paul's strategy in this pericope is religious coping in order to assure the Roman (and other) Christians of God's love for them in a hostile environment plagued by sufferings. In the Igbo context, where Christians are faced with different existential problems, Romans 8:35-38 becomes relevant in assuring Christians of God's ever abiding love for them irrespective of their sufferings.

In another vein, Uwaegbute (2019b:101-121) read Luke 4: 16-19 through the sociological conflict theory in the context of the ethnic minorities in Nigeria. According to Uwaegbute, Palestine of Jesus' days was rife with inequalities occasioned by uneven allocation of material resources dominated by a few elites; this is also the case of minority ethnic groups in Nigeria who are 'powerless' and 'voiceless'. For Uwagbute, Luke 4:16-19 therefore challenges the leaders of Nigeria to empower the ethnic minorities, politically, economically and socially. Similarly, Uwaegbute (2019) provided a 'social description' of the community of Luke dominated by 'class distinction' and 'wrongful use of wealth' in understanding why material possession was a problem in the Gospel of Luke, particularly as seen in Luke 12:13-15 and Luke 12:2130; this work was contextualised in Enugu state of Nigeria where materialism has hampered the practice of Christianity. The work called for a reorientation of the place of material possessions in the life of Christians, which will lead Christians in Enugu state to consider material possessions as secondary in the practice of Christianity and ensure a redistribution of wealth amongst them. Still adopting SSC, Silas (2016) studied the parable of the shrewd manager in Luke 16:1-9 in the Nigerian context. His work showed that the parable deals with right stewardship of wealth and possessions, which is a challenge to the rich (Christians) in Nigeria to attend to the material needs of the poor through the faithful use of wealth and possessions. Other non-contextual works by Nigerians that used SSC to read the New Testament included Ukwuegbu (2003) and Ukwuegbu (2008:538-559).

Whilst these Nigerian scholars used SSC as a methodology for their work, only Madubuko (2015) and Uwaegbute and Odo (2018) were detailed enough to name their methodologies as 'psychological-hermeneutical' and 'existential-psychological' approaches. This does not however negate the rigour and criticality applied in these works mentioned earlier. It is worth mentioning that these Nigerian scholars follow, clearly, the steps described by Elliot (1993) in using SSC as a methodology for interpreting the New Testament. This shows a great deal of commitment to the use of SSC in doing contextual works by these Nigerian New Testament scholars. 
As far as we found out, these are the few works performed by Nigerians in interpreting the New Testament using SSC both in the Nigerian context and beyond. What then accounts for this 'apathy' for SSC in interpreting the New Testament in Nigeria? Besides being conversant with ABS, part of the problem is theological reductionism. This, of course, is the belief that the New Testament is the word of God, which can only be interpreted theologically. Characteristic of Nigerian (African) Christian religiosity, most Nigerian biblical scholars (most of whom are church leaders) think that the New Testament as the word of God cannot be opened up to the researches and theories of the social sciences as this will rob it of its theological understandings. Whilst we cannot deny such a possibility (as has been seen in certain Marxist readings of the New Testament [Bello 1981 as an example]), we argue that the teachings presented in the New Testament cannot be satisfactorily and comprehensively understood or explained on theological considerations alone. Besides, as we have pointed out, these teachings of the New Testament are products of people(s) of different social settings. Also is the accusation of SSC being Eurocentric, which we had pointed out. Of course, most African scholars have labelled Western methodologies of interpreting the Bible in Africa as Eurocentric and have called for their outright rejection in biblical interpretation in Africa. Granted, this accusation of Eurocentrism with regard to Western methods of biblical interpretation in African is true; however, we are not forgetting the aim of this work, which is to find ways of supplementing ABS with SSC for a greater contextualisation of the New Testament texts in Nigeria. This is not a total abandonment of ABS but a cry for the incorporation of SSC in reading the New Testament texts for a more meaningful contextualisation. After all, other Eurocentric biblical methodologies such as historical, narrative, rhetorical, textual and redaction criticisms, amongst others, have all been used in interpreting the New Testament in the Nigerian context. Added to the problem is also 'intellectual laziness' that we explain to mean the inability of some New Testament scholars in Nigeria to go through the rigours involved in social sciences research approaches. Whilst it cannot be argued that the conventional methods of interpreting the New Testament (exegesis) are easy or simple, it seems that adopting SSC in interpreting the New Testament challenges the Nigerian biblical scholars to go beyond their 'comfort zone' to learn the research approaches of the social sciences, which are new to them. The rigours of this approach for some New Testament scholars in Nigeria are just too much of a burden to bear. This may also be linked with the fact that the curricula of most theological departments in universities and other institutions of learning in Nigeria do not incorporate social sciences methodologies for the science of biblical interpretation. Hence, curricula that do not make room for SSC will produce New Testament scholars who will not appreciate the need for SSC in the New Testament studies. This, in most cases, is the situation of the use of SSC in the interpretation of the New Testament in Nigeria.

\section{The necessity of social-scientific criticism in interpreting the New Testament in Nigeria}

As SSC began to develop from the 1960s up to the 1970s, so also began the agitation by African biblical scholars against Western-oriented biblical scholarship in interpreting the Bible in the African context. Scholars such as Mbiti (1963) began to read the New Testament through 'the African eyes'. This was the beginning of contextualisation - the reading of biblical texts to apply them in specific African contexts. From the 1970s, it seemed that contextualisation was becoming accepted as the best approach to the study of biblical texts in African contexts. The core drive for contextualisation is the belief that the African world, with its cultures and traditions, is very different from that of Western missionaries who introduced Christianity to Africans, especially those of the 19th- century missionary thrusts. This argument underlines the fact that African cultures influence how Africans understand the Bible. Hence, these cultures should influence biblical interpretation in Africa. Besides, some African biblical scholars began to point out that the world of the Bible is more like that of the Africans than that of the West (Chinwokwu 2015:272, 277). In contemporary times, contextualising the Bible in Africa is still a burning issue; it is equally an ongoing process (Ogunbanwo 2011:6-8) in African Christianity and biblical scholarship. This is still true of the study, understanding and application of the New Testament teachings in Nigeria. This is where we strongly argue that adopting methodologies that help to understand the world of the New Testament better would lead to purposeful contextualised readings of New Testament texts in Nigeria, particularly with the shifting contexts that Christians in Nigeria find themselves in as we have pointed out earlier.

Social-scientific criticism as a methodology places New Testament teachings firmly within their 1st century AD social world and uses proven theories and models taken from the social sciences to understand these teachings better. Secondly, such a methodology creates a basis for comparison and, then an application of these texts and teachings in the Nigerian context. This, we believe, should be the task of authentic contextualisation of biblical texts. As such, the use of SSC fits the task of contextualisation better in Nigeria; it prevents the reading of New Testament texts off-contexts, which is the bane of the New Testament interpretation in Nigeria today. Relatedly also is the issue of theological reductionism amongst New Testament scholars in Nigeria. As we have pointed out in this article, this is a problem facing the interpretation of the New Testament in Nigeria. Socialscientific criticism seriously guards the Nigerian New Testament interpreter against theological reductionism. It tells him or her that the New Testament as the word of God must be located firmly within its social world (context), and how an understanding of this social world can lead to a better understanding of these texts. This leads to the point of the 
argument of this study, that is, the need for supplementing ABS with SSC in contextualising New Testament texts in Nigeria.

It is undoubted that research is dynamic and progressive, so employing a new method such as SSC in interpreting biblical texts is apt and germane. For the serious-minded New Testament scholars in Nigeria, trying a new and evolving methodology such as SSC lets them key into new methodological developments in the study of the New Testament today. Of course, it has become certain that international New Testament scholarship now demands adopting newer and cutting-edge methodologies from scholars in the field. Thus, adopting SSC in this regard will help the Nigerian New Testament scholar key into this ongoing clamour for the use of newer methodologies in studying and interpreting the New Testament.

\section{Conclusion}

Social-scientific criticism has become a household methodology, especially in Western scholarship, for interpreting the New Testament. However, as discussed in this article, this has not been the case in Nigerian scholarship despite the gains of SSC in interpreting the New Testament. The article therefore argued that there is a need for Nigerians who are involved in interpreting the New Testament to strive to incorporate SSC as a methodology in interpreting the New Testament in the Nigerian context for a better contextualisation noting the changing contexts Christians find themselves in the country. This will also help New Testament scholars in Nigeria key in into mainline biblical scholarship all over the world.

\section{Acknowledgements Competing interests}

The authors declare that they have no financial or personal relationships that may have inappropriately influenced them in writing this article.

\section{Authors' contributions}

K.I.U., D.O.O. and C.I.U. contributed equally to this article.

\section{Ethical considerations}

This article followed all ethical standards for research without direct contact with human or animal subjects.

\section{Funding information}

This research received no specific grant from any funding agency in the public, commercial or not-for-profit sectors.

\section{Data availability}

Data sharing is not applicable to this article as no new data were created or analysed in this study.

\section{Disclaimer}

The views and opinions expressed in this article are those of the authors and do not necessarily reflect the official policy or position of any affiliated agency of the authors.

\section{References}

Adamo, D.T., 2016, 'African biblical studies: Illusions, realities and challenges', In die Skriflig 50(1), 1-10. https://doi.org/10.4102/ids.v50i1.1972

Asaju, D.F., 2005, 'Afro-centric biblical studies: Another recolonisation', in S.O. Abogunin (ed.), Decolonization of biblical interpretation in Africa, pp. 120-129, Nigerian Association for Biblical Studies, Ibadan.

Bello, F., 1981, A materialist reading of Mark, MaryKnoll, Orbis Books, New York, NY.

Bacharach, S.B., 1989, 'Organizational theories: Some criteria for evaluation', Academy of Management Review 14(4), 496-515. https://doi.org/10.5465/amr.1989.4308374

Bailey, K., 1983, Poet and peasant and through peasant eyes, William B. Eerdmans, Grand Rapids, MI.

Bailey, K., 2008, Jesus through the Middle Eastern eyes, IVP, IL.

Chinwokwu, E.N., 2015, A critical introduction to the traditions of Jesus, UNN Press, Nsukka.

Clarke, R.J., 2005, 'Research models and methodologies', HRR Seminar Series, viewed 10 June 2020, from http://www.vow.edu.au.

Craffert, P.F., 2008, The life of a Galilean Shaman: Jesus of Nazareth in anthropologicalhistorical perspective, James Clarke Co, Cambridge.

De Villiers, G., 2011, 'Andries van Aarde - A sideways glance: His theological and hermeneutical contribution to the South African scene', HTS Teologiese Studies Theological Studies 67(1), Art. \#1033, 10 pages. https://doi.org/10.4102/hts. v67i1.1033

Dube, M.W. \& West, G.O., 2000, The Bible in Africa: Transactions, trajectories and trends, Brill, Leiden.

Draper, J.A., 1992, 'The sociological function of the spirit/paraclete in the farewell discourse in the fourth Gospel', Neotestamentica 26(1), 13-29.

Draper, J.A., 1995, 'Wandering radicalism or purposeful activity? Jesus and the sending of messengers in Mark 6:6-56', Neotestamentica 29(2), 183-202.

Draper, J.A., 1998, 'Weber, Theissen and wandering Charismatics in the Didache', Journal of Early Christian Studies 6(4), 541-576. https://doi.org/10.1353/earl.1998.0070

Drovak, J., 2007, 'John H. Elliott's social-scientific criticism', Trinity Journal 28, 251-278.

Elliott, J.H., 1981, A home for the homeless: A sociological exegesis of 1 Peter, Fortress, Philadelphia, PA.

Elliott, J.H., 1993, What is social scientific criticism?, Fortress, Minneapolis, MN.

Elliott, J.H., 2008, 'From social description to social scientific criticism: The history of a society of Biblical literature section 1975-2015', BTB 38, 26-38. https://doi.org/10. 1177/01461079080380010401

Elliott, J.H., 2011, 'Social-scientific criticism: Perspectives, process and pay off. Evil eye at Galatia as illustration of the method', HTS Teologiese / Theological Studies 67(1), Art. \#858, 10 pages. https://doi.org/10.4102/hts.v67i1.858

Esler, P.F., 1994, The first Christians in their social worlds, Social scientific approaches to the New Testament interpretation, Routledge, New York, NY.

Esler, P.F., 1995, Modelling early Christianity: Social-scientific studies of the New Testament in its context, Routledge, New York, NY.

Esler, P.F., 1996, 'Group boundaries and intergroup conflict in Galatians: A new reading of Gal 5:13-16', in M.G. Brett (ed.), Ethnicity and the Bible, pp. 215-240, Brill, Leiden.

Esler, P.F., 2003, Conflict and identity in Romans, Fortress, Augsburg.

Gager, J., 1975, Kingdom and community: The social world of early Christianity, Prentice Hall, Hoboken, NJ.

Kato, B., 1975, Theological pitfalls in Africa, Evangel Publishing House, Nairobi.

Kissi, S. \& Van Eck, E., 2016, 'Ethnic reasoning in social identity of Hebrews: A socialscientific study', HTS Teologiese Studies/Theological Studies 73(3), a4489. https:// doi.org/10.4102/hts.v73i3.4489

Le Marquand, G., 2000, 'New Testament exegesis in Modern Africa', in G.O. Wes \& M.W. Dube (eds.), The Bible in Africa: Transactions, trajectories and trend, pp. 72-102, Brill, Leiden.

Longnecker, B.W., 2010, Remember the poor: Paul, poverty and the Greco-Roman world, William B. Eerdmans, Grand Rapids, MI.

Loumanen, P., 2010, Modelling in the social sciences: Interdisciplinary comparison, A paper presented at a workshop organized by TINT and the Helsinki collegium for Advanced Studies, June 17-18.

Madubuko, J.C., 2015, The Pauline spirit world in Ephesians 3:10 in the context of Igbo world view, A psychological-hermeneutical appraisal, Peter Lang, Frankfort.

Malina, B.J., 1982, 'The social sciences and Bible interpretation', Interpretation 36(3), 229-242. https://doi.org/10.1177/002096438203600302

Malina, B.J., 1983, 'Why interpret the Bible with the social sciences?', American Baptist Quarterly 2, 119-133. 
Malina, B.J. \& Rohrbaugh, R.L., 1992, Social-scientific commentary on the Synoptic Gospels, A/F, Minneapolis, MN.

Manus, C.U., 2003, Intercultural Hermeneutics in Africa: Methods and approaches, Action, Nairobi.

Martin, D., 1993, 'Social-scientific criticism', in S.L. McKenzie, S.N. Haynes (eds.) Each own meaning: An introduction to biblical criticism and their application pp. 125-141, John Knox, Kentucky, TX.

May, D.M., 1991, Social scientific criticism of the New Testament: A bibliography, Mercer, Macon, GA.

Mbiti, J.S., 1963, 'New Testament eschatology in an African background', Ph.D. thesis, University of Cambridge.

Mbuvi, A., 2017, 'African Biblical Studies: An introduction to an emerging discipline', Currents in Biblical Research 15(2), 149-178. https://doi.org/10.1177/ $1476993 \times 16648813$

Meeks, W.A., 1972, 'The man from heaven in Johannine sectarianism', Journal of Biblical Literature 91(1), 44-72. https://doi.org/10.2307/3262920

Meeks, W.A., 1983, The first urban Christians, Yale University Press, Yale, MI.

Nyiawung, M.D., 2010, 'Who is the Christ?: A scientific and narratological analysis from an African perspective', Ph.D. thesis, University of Pretoria.

Nyiawung, M.D., 2013, 'Contextualising biblical exegesis: What is the African biblical hermeneutical approach?', HTS Teologiese Studies/Theological Studies 69(1), Art. \#2011, 9 pages. http://dx.doi.org/10.4102/hts.v69i1.2011

Ogunbanwo, B.F., 2011, 'A socio-scientific reading in the Yoruba context of selected texts in Luke's Gospel portraying Jesus' attitude to outcasts: Implications for Anglican Dioceses in ljebu-Remo, Ogun State, Nigeria in the HIV and AIDS era', Ph.D. thesis, University of KwaZulu-Natal.

Okoye, M.K., 2018, 'Exegesis of Acts of the apostles 6:1-7 and the problems of social identity and intergroup relations in Nigeria', Ph.D. thesis, University of Nigeria.

Pilch, J.J. (ed.), 2001, Social scientific models for interpreting the Bible. Essays by the context group in honour of Bruce J. Malina, Brill, Leiden.

Silas, D.T., 2016, 'A social-scientific study of shrewd steward in Luke 16:1-9', M.Th dissertation, University of Stellenbosch.

Smith, J.Z., 1975, 'The social description of early Christianity' Religious Studies Review $1(1), 19-25$.

Theissen, G., 1978, The sociology of early Palestinian Christianity, Fortress, Philadelphia, PA.

Ukpong, J.S., 1996, 'The parable of the shrew manager (Lk 16:1-13): An essay in intercultural hermeneutics', Semeia $73,189-210$.

Ukpong, J.S., 2000, 'Developments in biblical interpretations in Africa: Historical and Hermeneutical directions', in G.O. West \& M.M Musa (eds.), Bible in Africa, transactions, trajectories and trends, pp. 11-28, Brill, Leiden.
Ukwuegbu, B.O., 2003, The emergence of Christian identity in Paul's letter to the Galatians: A social-scientific investigation into the root causes in the parting of way between Christianity and Judaism, Borengasser, Bonn.

Ukwuegbu, B.O., 2008, 'Paraenesis, identity-defining norms, or both? Galatians 5:13$6: 10$ in the light of social identity theory', CBQ 70(3), 538-559. https://doi. org/10.1353/neo.2019.0014

Uwaegbute, K.I., 2019a, 'Material possessions in the Gospel of Luke and their implications for Christians in Enugu state', PhD thesis, University of Nigeria.

Uwaegbute, K.I., 2019b, 'A social-scientific Reading of Luke 4:16-19 and the problem of ethnic minorities in Nigeria', Neotestamentica 53(1), 101-121.

Uwaegbute, K.I. \& Odo, D.O., 2018, 'An existential-psychological reading of Romans $8: 35-39$ in the context of Igbo Christianity', Neotestamentica 52(2), 333-357. https://doi.org/10.1353/neo.2018.0021

Van Aarde, A., 1993, 'Aspects of the social stratification of the advanced agrarian society in first-century Palestine' (original printed in Afrikaans)', HTS Teologiese Studies/Theological Studies 48(3\&4), 515-545.

Van Aarde, A., 1994, Kultuurhistoriese agtergrond van die Nuwe Testament: die eerste-eeuse Mediterreense sosiale konteks, Kital, Pretoria.

Van Aarde, A., 1997, 'Status identity, status envy and Jesus' Abba', Pastoral Psychology 45(6), 451-472. https://doi.org/10.1007/BF02310645

Van Aarde, A., 2002, 'Methods and models in the quest for the historical Jesus: Historical criticism and/or social scientific criticism?', HTS 58(2), 418-439. https:// doi.org/10.4102/hts.v58i2.562

Van Aarde, A., 2004, 'Social identity, status envy and Jesus as a fatherless child' in J.H. Ellens \& W.G. Rollins (eds.), Psychology and the Bible: A new pathway to read the scripture, vol. 4, pp. 223-246, Preaeger Press, Westport, CT.

Van Aarde, A., 2008, "Anthropological rabbits" and "positivistic ducks": An experiential reflection on Pieter Craffert's "shamanic Jesus", HTS Teologiese Studies/Theological Studies 64(2), 767-797. https://doi.org/10.4102/hts. v64i2.61

Van Eck, E., 2009a, 'Interpreting the parables of the Galilean Jesus: A social-scientific approach', HTS Teologiese Studies/Theological Studies 65(1), 310-321. https:// doi.org/10.4102/hts.v65i1.308

Van Eck, E., 2009b, 'When patrons are not patron: A social-scientific reading of the rich man and Lazarus (Lk 16:19-26)', HTS Teologiese Studies/Theological Studies 65(1), a309. https://doi.org/10.4102/hts.v65i1.309

Van Eck, E., 2013, 'When kingdoms are kingdoms no more: A social-scientific reading of the Mustard Seed (Lk 13:18-19)', Acta Theologica 33(2), 226-254. https://doi. org/10.4314/actat.v33i2.13

West, G.O., 2018, 'African Biblical scholarship as post-colonial, tri-polar and a site-ofstruggle', in T.B. Liew (ed.), Present and future of biblical studies, pp. 240-273, Brill, Leiden.

Wilde, J.A., 1974, 'A social description of the community reflected in the Gospel of Mark', PhD thesis, Drew University. 